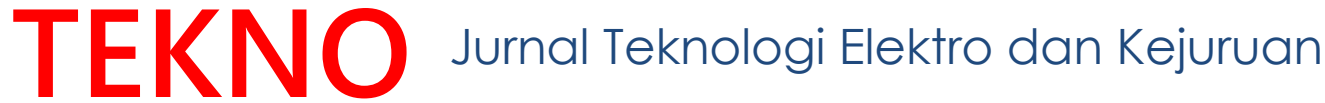

http://journal2.um.ac.id/index.php/tekno | ISSN 1693-8739 / 2686-4657

\section{Pengembangan aplikasi web dengan gamifikasi sebagai media pendukung pembelajaran untuk mata pelajaran pemrograman dasar}

\author{
Rahadyan Fannani Arif ${ }^{1}$, Harits Ar Rosyid ${ }^{2}$ \\ 1. Universitas Negeri Malang, Indonesia | rahadyan.fannani.1405334@students.um.ac.id \\ 2. Universitas Negeri Malang, Indonesia | harits.ar.ft@um.ac.id
}

\begin{abstract}
Abstrak
Siswa SMK dan MAK program keahlian Rekayasa Perangkat Lunak dituntut memiliki kemampuan pemrograman web. Mata pelajaran ini sangat penting dikarenakan banyak digunakan diindustri saat ini. Dan pengembangan dari teknologi web sendiri sangat beragam. Sehingga Mata Pelajaran ini penting untuk dipahami oleh siswa SMK jurusan RPL. Sedangkan penunjang untuk pembelajaran web di SMK masih kurang, dikarenakan siswa masih menggunakan cara konvensional. Permasalahannya adalah siswa banyak yang kurang memahami saat mengikuti instruksi yang ada di modul. Penelitian ini bertujuan mengembangkan Web Application sebagai penunjang pembelajaran dengan unsur gamifikasi. Metode yang digunakan dalam penelitian ini adalah metode penelitian dan pengembangan. Penelitian dan pengembangan ini menggunakan model pengembangan media model ADDIE dan model Prototyping. Hasil uji validasi yang dilakukan oleh para ahli, media yang dikembangkan dinyatakan valid, dengan persentase sebesar $95,24 \%$ oleh ahli materi dan $94,17 \%$ oleh ahli media. Berdasarkan uji coba kelayakan yang telah dilaksanakan di SMKN 4 Malang, diperoleh persentase sebesar $87,63 \%$ untuk uji coba kelompok kecil, dan $91,93 \%$ untuk uji coba kelompok besar. Dari rangkaian uji validasi dan uji coba tersebut, dapat dinyatakan bahwa secara keseluruhan, media yang dikembangkan telah valid dan layak digunakan sebagai penunjang proses pembelajaran mata pelajaran Pemrograman Dasar.
\end{abstract}

Kata Kunci

E-learning, gamifikasi, web application, pemrograman dasar, sekolah kejuruan 


\section{TEKNO Jurnal Teknologi Elektro dan Kejuruan}

http://journal2.um.ac.id/index.php/tekno | ISSN 1693-8739 / 2686-4657

\section{Pendahuluan}

Pemrograman Dasar merupakan salah satu mata pelajaran Dasar Program Keahlian yang wajib ditempuh siswa kelas X Program Keahlian Rekayasa Perangkat Lunak. Mata pelajaran Pemrograman Dasar adalah dasar untuk pembelajaran pemrograman lainnya seperti Pemrograman Web, Pemrograman Dekstop, dan lain-lain. Sehingga apabila kompetensi ini tidak dikuasai, akan menyulitkan siswa untuk memahami mata pelajaran pemrograman dengan tingkat lebih lanjut. Oleh karena itu, siswa dituntut untuk aktif dalam pembelajaran.

Berdasarkan hasil observasi wawancara dan lesson study yang dilakukan di SMKN 4 Malang, Platform yang digunakan untuk membuat interface yaitu Platform Web, sehingga siswa diharapkan untuk menguasai bahasa HTML, CSS, dan Javascript. Namun pemrograman interface ini menjadi sulit dimengerti dan dipahami dikarenakan banyaknya kombinasi bahasa pemrograman, sehingga siswa bingung dengan maksud dari script yang ditulisnya. Berdasarkan hasil observasi dan wawancara pada guru pengampu Pemrograman Dasar di SMKN 4 Malang, metode pembelajaran masih menggunakan metode konvensional, yaitu menggunakan modul yang berisikan materi dan soal praktek. Guru akan menjelaskan terlebih dahulu setelah itu siswa akan mengerjakan soal pada modul dengan menggunakan software Integrated Development Environment (IDE) di masing-masing perangkatnya.

Pembelajaran secara konvensional menggunakan modul yang kurang interaktif menghasilkan tingkat pemahaman materi pelajaran yang rendah (Rumansyah, 2016) dan hanya menekankan pada aspek kognitif peserta didik. Peserta didik hanya bersikap pasif dan merasa bosan. Sejalan dengan pernyataan tersebut, seorang pendidik yang menggunakan proses pembelajaran tradisional dengan hanya menjadikan buku sebagai sumber utama informasi dapat menjadikan peserta didik merasa bosan dan kurang tertarik pada mata pelajaran yang bersangkutan. Karena kurangnya interaktif dari media yang digunakan, siswa menjadi kurang aktif dalam mencari solusi dari soal yang diberikan (Yulia dan Arifin, 2016), dikarenakan feedback dari media yang digunakan masih kurang.

Gamifikasi adalah pendekatan pembelajaran menggunakan elemen-elemen di dalam permainan atau video game dengan tujuan memotivasi para peserta didik dalam proses pembelajaran dan memaksimalkan perasaan enjoy dan engagement terhadap proses pembelajaran tersebut (Jusuf, 2016; Suhendi dan Adriansyah, 2018). Selain itu, media ini dapat digunakan untuk menangkap hal-hal yang menarik minat siswa dan menginspirasinya untuk terus melakukan pembelajaran. Gamifikasi, memberikan alternatif untuk membuat proses belajar lebih menarik, menyenangkan, dan efektif (Prambayun dan Farozi, 2015; Maryanto dkk, 2017; Aini dkk, 2018; Farida dkk, 2018; Pratomo, 2018).

Berdasarkan permasalahan tersebut, peneliti tertarik untuk mengembangkan Media pembelajaran berbasis Web Application dengan gamifikasi. Web Application tersebut berisi konten pembelajaran untuk mata pelajaran pemrograman dasar kelas $\mathrm{X}$ dengan standar kompetensi sesuai dengan struktur kurikulum 2013 revisi 2017. Oleh sebab itu, penelitian ini dikembangkan dengan judul "Pengembangan Web Application dengan Menggunakan 


\section{TEKNO Junal Teknologi Elekro dan Kejurvon}

http://journal2.um.ac.id/index.php/tekno | ISSN 1693-8739 / 2686-4657

Gamifikasi Sebagai Media Pendukung Pembelajaran untuk Mata Pelajaran Pemrograman Dasar Kelas X di SMKN 4". Web Application tersebut menyediakan sarana bagi pendidik untuk membuat courses online berbentuk Interactive Coding dengan teknik gamifikasi.

\section{Metode}

Penelitian dan pengembangan produk ini menggunakan model ADDIE. Model ADDIE terdiri dari lima tahapan pengembangan media pembelajaran (Trisiana dan Wartoyo, 2016) yaitu: analisis, desain, pengembangan, implementasi, dan evaluasi. Sedangkan di bagian pengembangan menggunakan metodologi pengembangan perangkat lunak Prototyping. Diagram model pengembangan ADDIE dan prototyping ditunjukkan seperti pada Gambar 1.

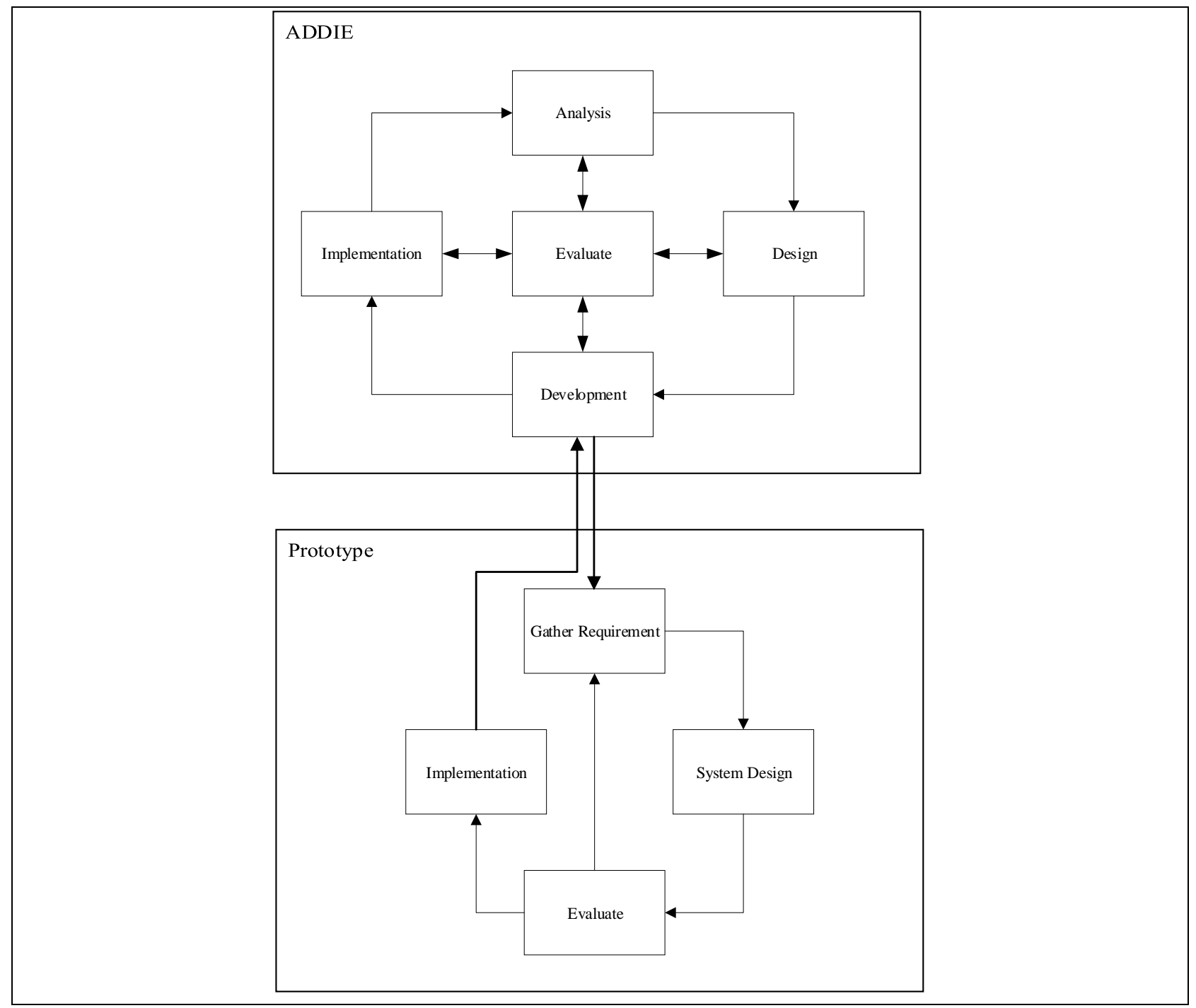

TEKNO Vol. 29 Issue 2, p161-177 | Jurusan Teknik Elektro, Universitas Negeri Malang, Indonesia | September 2019

R. F. Arif, H. A. Rosyid | Pengembangan aplikasi web dengan gamifikasi sebagai media pendukung... 


\section{TEKNO Jurnal Teknologi Elektro dan Kejuruan}

http://journal2.um.ac.id/index.php/tekno | ISSN 1693-8739 / 2686-4657

Gambar 1. Diagram model pengembangan ADDIE dan prototyping

1) Tahap Analisa

Sebelum melakukan analisa kebutuhan perlu dilakukan identifikasi masalah mengenai proses pembelajaran pada mata pelajaran pemrograman dasar pada SMKN 4 Malang. Untuk mengidentifikasi masalah tersebut dilakukan observasi wawancara dan lesson study. Setelah permasalahan telah ditemukan, selanjutnya dapat diidentifikasi kebutuhan dalam pengembangan Web Application untuk pembelajaran pemrograman dasar. Analisa kebutuhan ini digunakan sebagai acuan dalam pengembangan media pembelajaran nantinya. Hal yang dianalisa adalah kebutuhan dari guru dan siswa, jenis bahan ajar yang akan dikembangkan dan materi Pemrograman Dasar yang akan dijadikan materi

2) Tahap Desain

Pada tahapan ini dilakukan perencanaan desain sistem yang digunakan sebagai media pembelajaran pemrograman dasar sesuai dari hasil pada tahap analisis. Tahap ini terdiri dari perancangan materi, perancangan UML (use case, flow diagram, dan flowchart) dan perancangan antar muka pengguna, menyusun instrumen pengujian, serta evaluasi.

3) Tahap Pengembangan

a) Analisis Kebutuhan Sistem

Analisis dilakukan untuk melihat berbagai komponen yang dipakai sistem yang sedang berjalan meliputi hardware, software, jaringan dan sumber daya manusia. Analisa kebutuhan sistem dari media yang dikembangkan adalah sebagai berikut: (a) Dapat menangani minimal 45 koneksi secara simultan; (b) Komunikasi data secara Real-Time untuk menangani fitur gamifikasi; (c) Dapat berkomunikasi dua arah antara Server dan Client; (d) Dapat bekerja secara offline; (e) Keamanan API; (f) Dapat dikembangkan berkelanjutan.

b) Desain Sistem

Sistem akan dibagi menjadi 2 bagan yaitu bagian client dan API Server. Pada bagian client terdapat 3 teknologi utama, yaitu single page application yang digunakan sebagai tempat user interface dari aplikasi yang berjalan, state management yang digunakan untuk mengolah state pada web application, dan local storage yang digunakan untuk menyimpan data pada sisi client. Pada bagian API Server terdapat 4 komponen utama yaitu authentication yang bertugas untuk memberikan otorisasi dan menentukan hak akses terhadap pengguna, API Query yang digunakan sebagai metode untuk komunikasi dengan server, nodejs yang digunakan sebagai bahasa pemrograman di sisi server, dan MongoDB yang digunakan sebagai database pada server. 


\section{TEKNO Jurnal Teknologi Elektro dan Kejuruan}

http://journal2.um.ac.id/index.php/tekno | ISSN 1693-8739 / 2686-4657

c) Membangun Prototype

Pada tahap ini dibuat prototype dengan konsep yang sederhana dan fitur yang minimal dengan pembuatan secepat mungkin tetapi dapat memenuhi kebutuhan inti pengguna atau disebut juga dengan Minimum Viable Product (MVP). Pembuatan MVP ini digunakan untuk menvalidasi apakah fungsi dasar, User Interface dan User Experience yang akan dibuat dapat sesuai dengan tujuan pengembangan ini. Pada MVP ini akan dikembangkan produk dengan alur utama aplikasi yaitu mulai daftar pengguna sampai penentuan score pemain, tanpa fitur tambahan seperti Leaderboard, Social, Achievement dan lain-lain.

d) Pengujian Sistem

Pada tahap ini akan dilakukan uji coba terhadap prototype, apakah sudah sesuai dengan apa yang diharapkan. Hasil dari uji coba tersebut akan dijadikan evaluasi apakah prototype tersebut masih memiliki kekurangan, jika masih terdapat kekurangan maka akan diperbaiki dan dilakukan uji coba kembali. Hal yang perlu divalidasi adalah fungsi dasar, User Interface dan User Experience.

e) Implementasi Sistem

Pada tahap ini aplikasi web akan di deploy ke server sehingga dapat diakses melalui koneksi internet. Untuk proses deployment ini menggunakan alat yang bernama Docker. Docker adalah platform yang digunakan untuk menjalankan aplikasi web dimanapun menggunakan wadah (Container) sehingga memungkinkan suatu aplikasi web berjalan di lingkungan manapun dengan konsisten. Container sendiri adalah suatu konsep yang menggantikan model virtual machine dengan ukuran yang lebih kecil dan beban yang ringan.

4) Tahap Desain

Pada tahapan ini media pembelajaran akan diimplementasikan pada siswa kelas X RPL di SMK Negeri 4 Malang untuk dilakukan uji coba akhir. Siswa akan mencoba mengoperasikan media pembelajaran yang sudah dikembangan sebelum nantinya siswa diminta untuk menilai media pembelajaran di tahap evaluasi. Uji coba ini terdapat 2 siklus yaitu uji coba kelompok kecil sejumlah 12 orang dan uji coba kelompok besar sejumlah 30 orang.

5) Tahap Evaluasi

Pada model penelitian dan pengembangan ADDIE, terdapat tahap evaluasi yang dilakukan di setiap tahapan. Tahapan ini digunakan untuk memperbaiki pada setiap tahapan jika terdapat hal yang tidak sesuai. Dengan adanya tahapan ini proses penelitian dan 


\section{TEKNO Jurnal Teknologi Elektro dan Kejuruan}

http://journal2.um.ac.id/index.php/tekno | ISSN 1693-8739 / 2686-4657

pengembangan menjadi lebih dinamis dan pada akhirnya dapat menyesuaikan dengan kondisi di lapangan, sehingga produk yang dihasilkan lebih maksimal. Validasi dan uji coba produk terdiri dari beberapa langkah, yaitu:

a) Validasi Produk

Validasi produk terdapat dua bagian, yaitu validasi media dan validasi materi. Ahli media dan materi untuk pengembangan media ini dilakukan oleh dosen Program Studi Pendidikan Teknik Informatika, Teknik Elektro, Universitas Negeri Malang yang telah kompeten dibidangnya dan guru pengampu mata pelajaran Pemrograman Dasar kelas X RPL di SMK Negeri 4 Malang. Ahli media bertugas menilai kelayakan dari media yang telah dikembangkan.

b) Uji Coba Kelompok Kecil

Subjek uji coba pada kelompok kecil menggunakan 12 siswa kelas X RPL SMK Negeri 4 Malang sebagai sampel dan dipilih dari rentang dibawah rata-rata, sedang, dan di atas ratarata.

c) Uji Coba Kelompok Besar

Uji coba kelompok besar dilakukan oleh siswa kelas X RPL di SMK Negeri 4 Malang. Pada uji coba lapangan ini siswa yang diambil sebagai sampel lebih banyak daripada uji coba kelompok kecil. Siswa yang digunakan sebagai sampel minimal 30 orang. Pada tahap inilah yang menentukan media dikatakan valid atau tidak.

Jenis data yang didapat dari uji coba diatas adalah data kuantitatif dan data kualitatif. Data kuantitatif dalam penelitian ini ialah penilaian media dari hasil angket yang disebarkan kepada ahli media, ahli materi, dan peserta didik kelas X Program Keahlian RPL dari SMK Negeri 4 Malang. Dari angket tersebut akan diperoleh data dengan menghitung skor jawaban. Data kualitatif merupakan data yang berbentuk kalimat, kata, atau gambar. Dalam penelitian ini, data kualitatif didapatkan dari tanggapan oleh ahli materi, ahli media, dan responden. Data tersebut berupa kritik, saran, dan komentar mengenai media.

Angket tersebut menggunakan teknik 4 skala likert, agar tidak terdapat jawaban ragu-ragu dari subjek uji coba. Berdasarkan data kuantitatif tersebut akan diketahui tingkat kevalidan dan kelayakan dari bahan ajar yang dikembangkan. Dalam penentuan hasil kelayakan/kevalidan dilakukan dengan menggunakan kriteria penilaian yang dapat dilihat pada Tabel 1.

Tabel 1. Kriteria penilaian kelayakan bahan ajar

\begin{tabular}{|c|c|c|c|}
\hline No & Persentase & Indikator & Keterangan \\
\hline 1 & $76 \%-100,00 \%$ & Valid & Layak dan tidak perlu direvisi \\
\hline 2 & $51 \%-75,00 \%$ & Cukup valid & Cukup layak dan perlu revisi kecil \\
\hline 3 & $26 \%-50,00 \%$ & Kurang valid & Kurang layak dan perlu revisi sebagian \\
\hline
\end{tabular}

TEKNO Vol. 29 Issue 2, p161-177 | Jurusan Teknik Elektro, Universitas Negeri Malang, Indonesia | September 2019 R. F. Arif, H. A. Rosyid | Pengembangan aplikasi web dengan gamifikasi sebagai media pendukung... 


\section{TEKNO Jumal Teknologi Elekrio dan Kejurron}

http://journal2.um.ac.id/index.php/tekno | ISSN 1693-8739 / 2686-4657

$4<26 \% \quad$ Tidak valid $\quad$ Tidak valid gunakan dan perlu revisi keseluruhan

\section{Hasil dan Pembahasan}

Media pembelajaran yang dihasilkan berupa Web Application yang berisi konten pembelajaran untuk mata pelajaran pemrograman dasar kelas $X$ dengan standar kompetensi sesuai dengan struktur kurikulum 2013 revisi 2017 yang dikemas dengan gamifikasi. Materi pembelajaran yang diajarkan yaitu HTML, CSS, dan Javascript. Dalam media pembelajaran ini, peserta didik akan melakukan programming secara daring. Sistem secara realtime akan menampilkan hasil dari script yang ditulis oleh peserta didik. Berikut merupakan hasil tampilan antarmuka media pembelajaran:

1) Halaman Welcome

Halaman ini berisi pengenalan media pembelajaran, Pada header terdapat dua menu, yaitu menu daftar dan masuk. Menu daftar akan membawa pengguna ke halaman pendaftaran, sedangkan menu masuk akan membawa pengguna ke halaman masuk yang digunakan untuk melakukan otentikasi untuk masuk ke media pembelajaran. Selain itu terdapat menu mulai yang ditujukan untuk pengguna yang baru memulai. Gambar 2.

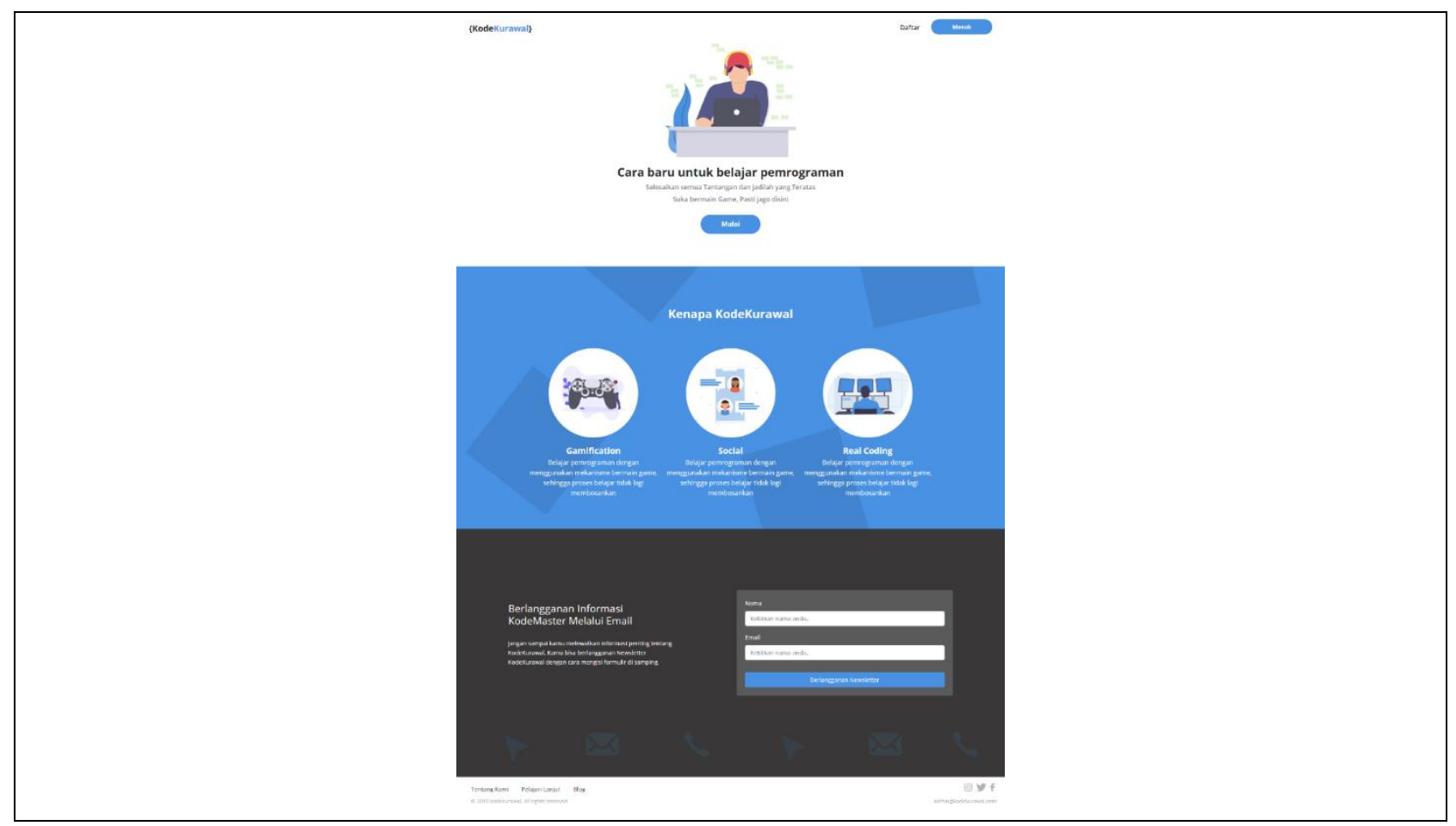

Gambar 2. Halaman Welcome 


\section{TEKNO Jumal Teknologi Eektro dan Kejurvon}

http://journal2.um.ac.id/index.php/tekno | ISSN 1693-8739 / 2686-4657

2) Halaman Sign In

Halaman Sign In digunakan untuk melakukan autentikasi sebelum masuk ke media pembelajaran. Pada Form Sign In terdapat 2 input yaitu email dan password, selain itu terdapat 2 tombol yaitu tombol SIGN IN yang digunakan untuk melakukan autentikasi dan tombol SIGN UP yang akan membawa pengguna ke halaman pendaftaran. Jika email dan password yang dimasukkan sudah benar maka akan dialihkan ke halaman dashboard user, jika salah maka akan keluar peringatan bahwa email atau password salah (Gambar 3).

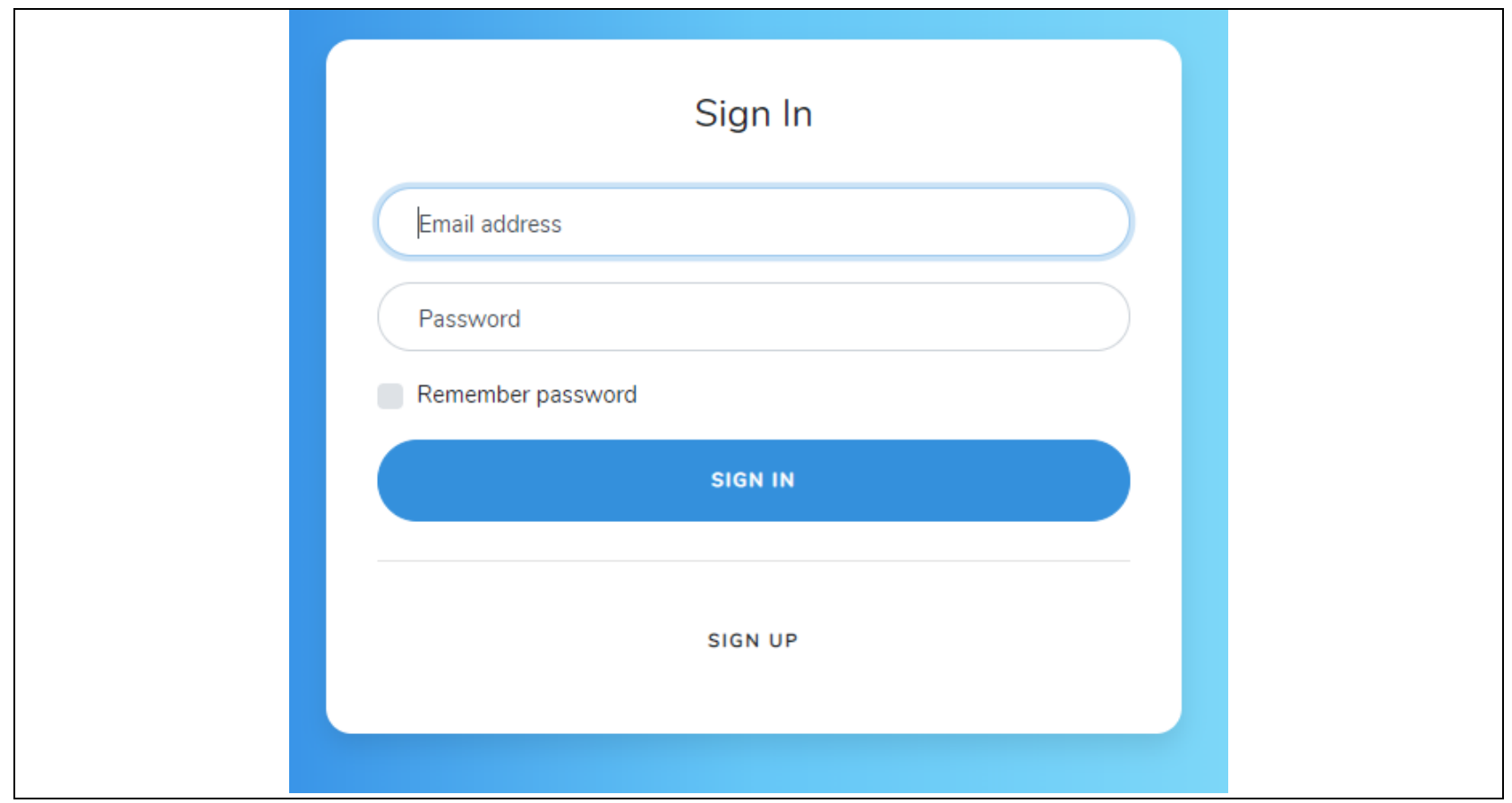

Gambar 3. Halaman Sign In

3) Halaman Sign Up

Halaman Sign Up (Gambar 4) digunakan untuk melakukan pendaftaran jika pengguna belum memiliki akun. Pada halaman Sign Up terdapat 3 input yaitu nama, email, dan password yang wajib untuk diisi. Jika pengguna sudah melengkapi form tersebut, maka selanjutnya yaitu menekan tombol SIGN UP yang digunakan untuk mengirim data pendaftaran ke server dan menyimpannya, jika proses pendaftaran berhasil maka halaman akan dialihkan ke halaman Sign In, jika gagal maka akan keluar peringatan seperti kalau email sudah ada yang menggunakan. 


\section{TEKNO Junal Teknologi Eekrto dan Kejuruan}

http://journal2.um.ac.id/index.php/tekno | ISSN 1693-8739 / 2686-4657

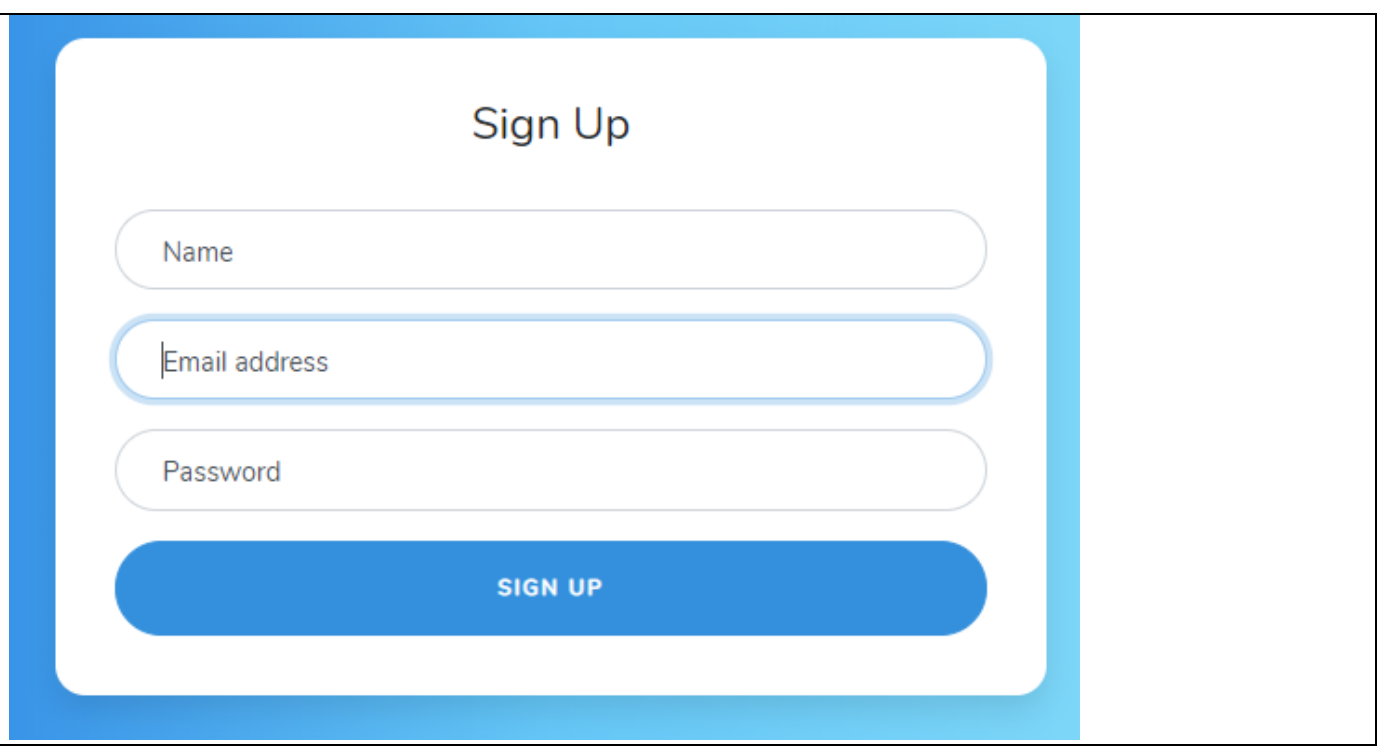

Gambar 4. Halaman Sign Up

4) Halaman Dashboard

Halaman Dashboard (Gambar 5) adalah halaman awal setelah pengguna melakukan otentikasi. Halaman ini akan menampilkan rangkuman progress pengguna. Data yang ditampilkan yaitu total achievement, badges, dan stars yang berhasil dikumpulkan oleh siswa. Selain itu terdapat informasi level dan experience point (exp), semakin tinggi nilai exp maka level juga semakin tinggi. Dibawah bagian User Summary terdapat bagian My Course dan Daily Target. My Course adalah daftar pembelajaran yang sedang diambil oleh pengguna. Sedangkan Daily Target adalah target harian exp yang harus dicapai untuk mendapatkan achievement.

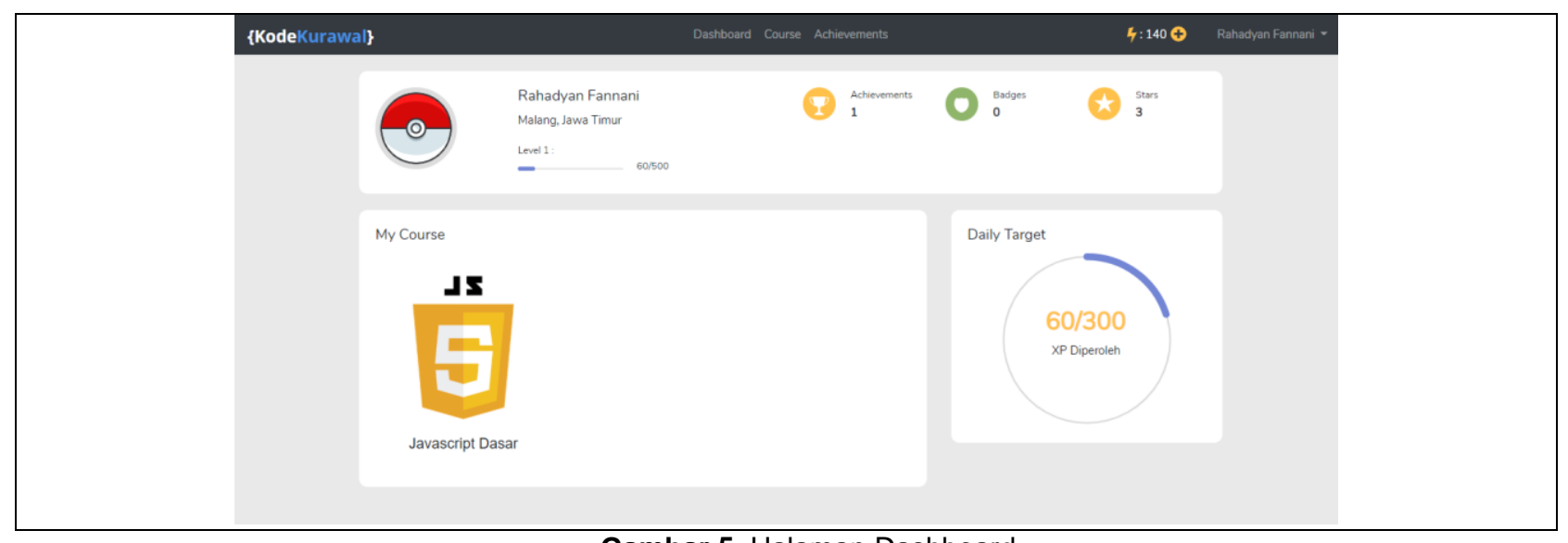

Gambar 5. Halaman Dashboard 


\section{TEKNO Jumal Teknologi Elektro dan Kejivruan}

http://journal2.um.ac.id/index.php/tekno | ISSN 1693-8739 / 2686-4657

5) Halaman Achievement

Pada halaman achievement (Gambar 6) terdapat 2 bagian yaitu achievement dan badges. Untuk mendapatkan achievement pengguna harus memenuhi syarat yang ada pada achievement tersebut. Jika berhasil terpenuhi maka bintang akan bertambah dan akan muncul syarat baru yang lebih menantang untuk mendapatkan bintang berikutnya. Badges didapatkan jika pengguna berhasil menyelesaikan 1 course. Pada contoh diatas pengguna mendapatkan badges "Dasar Javascript" yang berarti pengguna sudah menyelesaikan Course "Dasar Javascript".

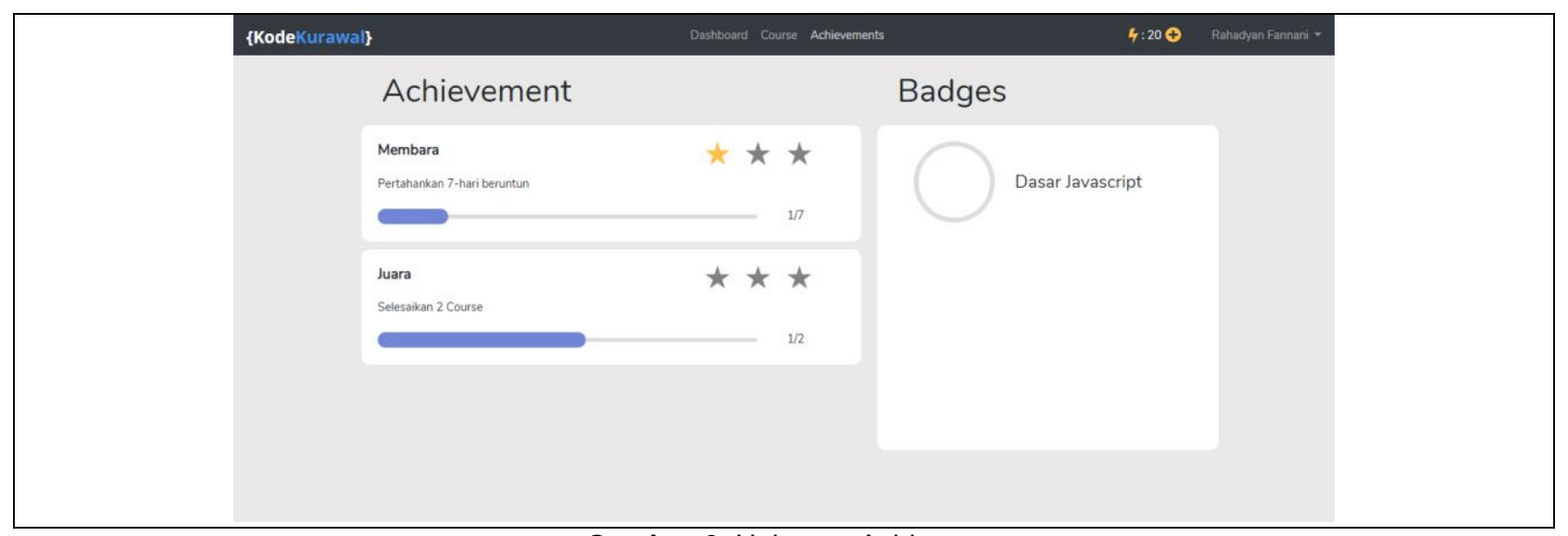

Gambar 6. Halaman Achievement

6) Halaman Daftar Course

Halaman Daftar Course (Gambar 7) menampilkan semua Course yang bisa diambil oleh pengguna. Pada gambar diatas terdapat 3 Course yaitu HTML Dasar, CSS Dasar, dan Javascript Dasar. Setiap pengguna bebas untuk memilih course yang akan dijalankan. Pada setiap course ini nantinya akan terdapat beberapa stage yang harus diselesaikan secara berurutan.

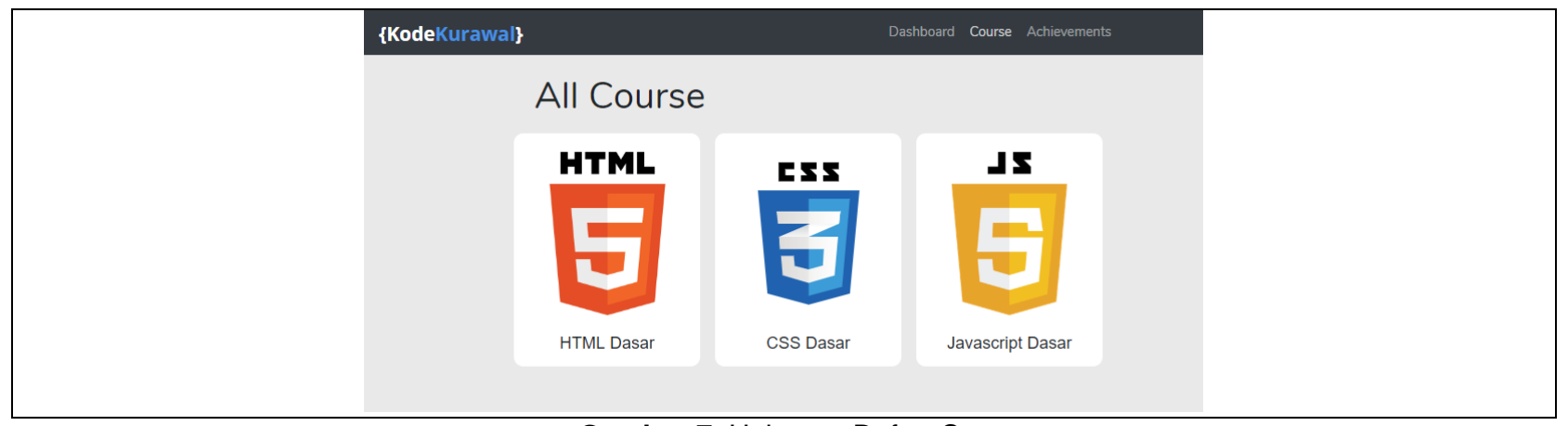

Gambar 7. Halaman Daftar Course

TEKNO Vol. 29 Issue 2, p161-177 | Jurusan Teknik Elektro, Universitas Negeri Malang, Indonesia | September 2019

R. F. Arif, H. A. Rosyid | Pengembangan aplikasi web dengan gamifikasi sebagai media pendukung... 


\section{TEKNO Jumal Teknologi Eektro dan Kejuruon}

http://journal2.um.ac.id/index.php/tekno | ISSN 1693-8739 / 2686-4657

7) Halaman Daftar Stage

Halaman ini akan menampilkan daftar Stage dari Course beserta dengan Leaderboard score tertinggi yang berhasil didapatkan oleh pengguna pada Course tersebut (Gambar 8). Stage harus diselesaikan secara berurutan, Stage dengan ikon gembok adalah Stage yang masih belum bisa dimainkan dikarenakan Stage sebelumnya belum berhasil diselesaikan. Jika pengguna sudah berhasil menyelesaikan stage tersebut, maka akan keluar icon bintang yang menandakan bintang yang berhasil didapatkan oleh pengguna pada stage tersebut. Pada bagian learderboard akan muncul 10 nama pengguna yang berhasil mendapatkan score akumulatif tertinggi pada course tersebut.

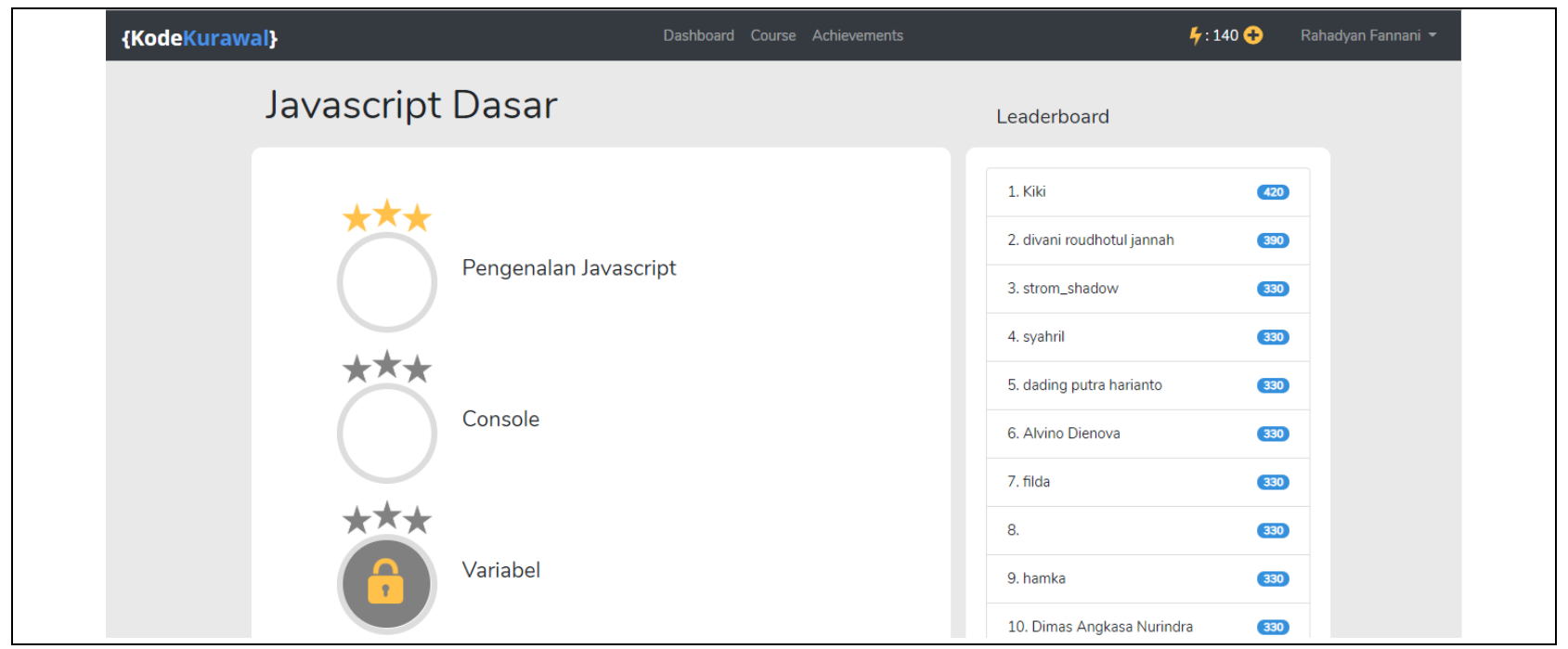

Gambar 8. Halaman Daftar Stage

8) Halaman Stage

Halaman Stage (Gambar 9) adalah halaman dimana pengguna akan melakukan proses pembelajaran dengan cara menyelesaikan misi-misi yang ada pada halaman tersebut. Disini pengguna dituntut untuk menyelesaikan misi tersebut dengan waktu sesingkatsingkatnya dan minim kesalahan untuk mendapatkan skor yang tinggi. Pada Halaman Stage terdapat 5 bagian yaitu bagian Status Bar, Guide, Interactive Coding, Output dan Navigation. Setiap bagian tersebut memiliki fungsionalitasnya masing-masing untuk membantu siswa dalam proses pembelajaran. 


\section{TEKNO Jurnal Teknologi Elektro dan Kejuruan}

http://journal2.um.ac.id/index.php/tekno | ISSN 1693-8739 / 2686-4657

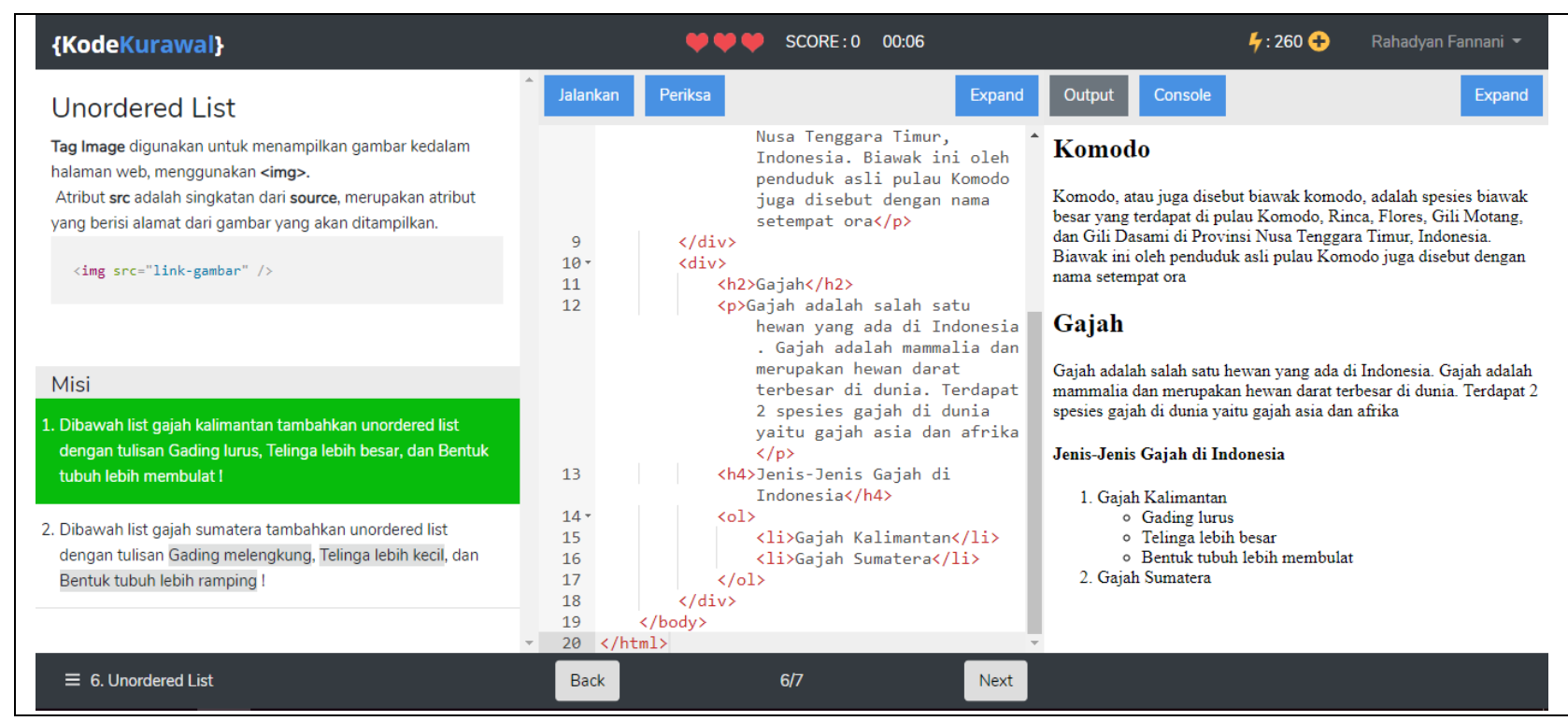

Gambar 9. Halaman Stage

Pada bagian Status Bar terdapat informasi nyawa, skor, dan waktu. Nyawa akan berkurang jika pengguna melakukan kesalahan saat pemeriksaan kode. Jika nyawa habis maka pengguna harus mengulang stage tersebut. Informasi skor akan bertambah setiap pengguna berhasil menyelesaikan misi. Informasi waktu memberikan informasi tentang berapa lama pengguna dalam pengerjaan. Semakin singkatnya waktunya maka semakin baik.

Bagian navigasi berfungsi untuk melakukan navigasi antar stage, dan melihat daftar Stage dari Course yang sedang dijalankan. Navigasi hanya dapat dilakukan pada stage yang sudah terbuka. Terdapat 2 bagian navigasi yaitu dibagian sidebar yang menampilkan daftar stage pada course yang dijalankan, dan di bagian footer yang digunakan untuk melakukan navigasi secara maju atau mundur.

Bagian Guide akan menampilkan materi yang berkaitan dengan Stage tersebut materi tersebut nantinya akan dibaca oleh siswa terlebih dahulu sebelum melanjutkan untuk mengerjakan misi. Materi tersebut bersifat rich content, dalam artian tidak hanya media tulisan yang bisa ditampilkan melainkan bisa juga gambar, audio, maupun video. Selain itu bagian guide juga menampilkan daftar misi yang harus diselesaikan oleh pengguna. Daftar misi tersebut akan berwarna hijau jika sudah berhasil diselesaikan.

Bagian Interactive Coding adalah tempat bagi pengguna untuk menuliskan script sesuai dengan misi yang harus diselesaikan. Seperti layaknya pada editor pemrograman, pada Interactive Coding ini juga terdapat Syntax Highlighting untuk memudahkan pengguna dalam melakukan pemrograman. Pada bagian ini terdapat 3 tombol yaitu Jalankan, Periksa, dan Expand. Tombol Jalankan digunakan untuk menjalankan script dan hasilnya akan ditampilkan pada bagian Output. Tombol Periksa digunakan untuk mengirimkan script jika sudah dirasa 


\section{TEKNO Jurnal Teknologi Elektro dan Kejuruan}

http://journal2.um.ac.id/index.php/tekno | ISSN 1693-8739 / 2686-4657

benar untuk diverifikasi apakah script yang diketik sudah sesuai dengan persyaratan misi. Tombol Expand digunakan untuk memperluas bagian Interactive Coding.

Bagian Output berfungsi seperti layaknya browser, bagian ini akan menampilkan hasil output sesuai dengan script yang diketik. Terdapat 3 tombol yaitu Output, Console, dan Expand. Tombol Output digunakan untuk mengganti tampilan sehingga bisa menampilkan hasil render dari script HTML dan CSS yang sudah diketikkan. Sedangkan tombol Console digunakan untuk menampilkan output console yang dituliskan di javascript. Tombol Expand digunakan untuk memperluas tampilan Output untuk memudahkan pengguna dalam melihat tampilan website.

Setelah semua misi berhasil diselesaikan maka akan tampil Score Board yang berisi informasi skor, waktu selesai, dan bintang yang berhasil didapatkan. Terdapat beberapa tombol pada Score Board yaitu tombol Lanjut, Main lagi, dan Kembali. Tombol lanjut hanya muncul jika pengguna berhasil menyelesaikan stage tersebut. Tombol lanjut berfungsi untuk berpindah ke stage selanjutnya. Tombol Main lagi digunakan untuk mengulang Stage yang berjalan. Sedangkan tombol Kembali digunakan untuk kembali ke halaman daftar Stage.

Gambar 16 adalah dialog peringatan yang muncul jika pengguna keluar dari Stage yang belum diselesaikan. Hal tersebut berfungsi untuk menghindari jika pengguna menekan tombol keluar secara tidak sengaja, sehingga proses pembelajaran tidak hilang. Jika pengguna menekan tombol no maka pengguna tidak akan dialihkan dan bisa tetap untuk mengerjakan course. Sedangkan jika menekan tombol yes, maka akan langsung dialihkan ke halaman yang dituju dan progress dari pengerjaan course tersebut akan hilang.

Hasil yang didapat dari validasi media berupa saran dan tingkat kevalidan dari produk tersebut. validasi ahli media. Tingkat kevalidan memperoleh persentase sebesar $94,17 \%$ dengan kriteria sangat valid. hasil rata-rata ahli media tersebut masuk kategori valid tetapi perlu untuk revisi dikarenakan masih ada beberapa kekurangan yaitu misi yang belum sesuai dengan kode program, penulisan huruf besar dan kecil, dan skor yang belum real-time. Untuk rincian persentase setiap aspek dapat dilihat pada Tabel 2.

Tabel 2. Hasil validasi ahli media

\begin{tabular}{lcccc}
\hline \multicolumn{1}{c}{ Aspek } & $\sum$ Tse & $\sum$ Tsh & V (\%) & Kriteria \\
\hline Rekayasa Perangkat Lunak & 44 & 48 & 91,67 & Sangat Valid \\
Desain Pembelajaran & 30 & 32 & 93,75 & Sangat Valid \\
Komunikasi Visual & 39 & 40 & 97,50 & Sangat Valid \\
\hline
\end{tabular}

Hasil yang didapat dari validasi media berupa saran dan tingkat kevalidan dari produk tersebut. Validasi ahli materi oleh guru jurusan RPL di SMK Negeri 4 Malang Malang. Hasil uji coba validasi ahli materi mendapatkan persentase sebesar 95,24 \%. Hasil rata-rata ahli materi tersebut masuk kategori valid dan tidak ada revisi dikarenakan sudah memenuhi kebutuhan aplikasi. Namun ahli materi memberikan saran untuk memperbaiki tampilan (tombol, form, dan icon) sehingga siswa lebih tertarik dan mampu untuk menyerap materi lebih baik. Untuk rincian persentase setiap aspek dapat dilihat pada Tabel 3. 


\section{TEKNO Jurnal Teknologi Elektro dan Kejuruan}

http://journal2.um.ac.id/index.php/tekno | ISSN 1693-8739 / 2686-4657

Tabel 3. Hasil validasi ahli materi

\begin{tabular}{lcccc}
\hline \multicolumn{1}{c}{ Aspek } & $\sum$ Tse & $\sum$ Tsh & V (\%) & Kriteria \\
\hline Isi & 44 & 48 & 91,67 & Sangat Valid \\
Bahasa & 30 & 32 & 93,75 & Sangat Valid \\
Penyajian & 39 & 40 & 97,50 & Sangat Valid \\
\hline
\end{tabular}

Uji coba kelompok kecil dilakukan oleh 12 orang siswa SMK Negeri 4 Malang. Uji coba dilakukan menggunakan angket uji coba responden. Hasil uji coba kelompok kecil mendapatkan persentase sebesar 87,63 \%. Berdasarkan kriteria penilaian pada Tabel 3.7, hasil tersebut masuk kategori valid dan tidak memerlukan revisi. Berdasarkan data yang diperoleh dari hasil uji coba kelompok kecil, terdapat 2 aspek yang dinilai yang meliputi: (1) Aspek rekayasa perangkat lunak; dan (2) Aspek Komunikasi Visual;

Dilihat dari aspek rekayasa perangkat lunak yang digunakan untuk mengukur tingkat kelayakan media pembelajaran berdasarkan: (1) Usabilitas (kemudahan penggunaan media pembelajaran); (2) Kelengkapan konten; dan (3) Petunjuk penggunaan media. Dari hasil uji coba kelompok kecil, skor yang didapat sebesar $86,28 \%$. Hal ini menandakan bahwa media pembelajaran telah memenuhi kriteria valid dalam aspek rekayasa perangkat lunak. Namu masih belum sempurna, sehingga perlu untuk dilakukan perbaikan terhadap media pembelajaran khususnya pada aspek rekayasa perangkat lunak sehingga dapat menutupi kekurangan tersebut.

Dilihat dari aspek komunikasi visual yang digunakan untuk mengukur tingkat kelayakan media pembelajaran berdasarkan: (1) Komunikatif; (2) Visual; (3) Layout interaktif; (4) Audio; dan (5) Keterbacaan konten. Dari hasil uji coba kelompok kecil, skor yang didapat sebesar 91,67\%. Hal ini menunjukkan bahwa E-Modul telah memenuhi kriteria valid dalam aspek komunikasi visual. Namun skor tersebut masih belum sempurna, sehingga perlu dilakukan perbaikan terhadap media pembelajaran khususnya pada aspek komunikasi visual, sehingga dapat menutupi kekurangan tersebut. Untuk rincian persentase setiap aspek dapat dilihat pada Tabel 4 .

Tabel 4. Hasil uji coba kelompok kecil

\begin{tabular}{lcccc}
\hline \multicolumn{1}{c}{ Aspek } & STse & $\sum$ Tsh & V (\%) & Kriteria \\
\hline Rekayasa Perangkat Lunak & 497 & 576 & 86,28 & Sangat Valid \\
Komunikasi Visual & 176 & 192 & 91,66 & Sangat Valid \\
\hline
\end{tabular}

Uji coba kelompok besar dilakukan oleh 30 orang siswa SMK Negeri 4 Malang. Hasil uji coba kelompok besar mendapatkan persentase sebesar $91,93 \%$. Berdasarkan kriteria penilaian hasil tersebut masuk kategori valid dan tidak memerlukan revisi.

Berdasarkan data yang diperoleh dari hasil uji coba kelompok besar, terdapat 2 aspek yang dinilai yang meliputi: (1) Aspek rekayasa perangkat lunak; dan (2) Aspek komunikasi visual.

Dilihat dari aspek rekayasa perangkat lunak yang digunakan untuk mengukur tingkat kelayakan media pembelajaran berdasarkan: (1) Usabilitas (kemudahan penggunaan media 


\section{TEKNO Jurnal Teknologi Elektro dan Kejuruan}

http://journal2.um.ac.id/index.php/tekno | ISSN 1693-8739 / 2686-4657

pembelajaran); (2) Kelengkapan konten; dan (3) Petunjuk penggunaan media. Dari hasil uji coba kelompok besar, skor yang didapat sebesar 91,67\%. Hal ini menandakan bahwa E-Modul telah memenuhi kriteria valid dalam aspek rekayasa perangkat lunak. Namun skor tersebut masih belum sempurna, sehingga masih menunjukkan bahwa masih ada sedikit kekurangan pada media pembelajaran. Oleh karena itu perlunya dilakukan perbaikan terhadap media pembelajaran khususnya pada aspek rekayasa perangkat lunak, sehingga dapat menutupi kekurangan tersebut.

Dilihat dari aspek komunikasi visual yang digunakan untuk mengukur tingkat kelayakan media pembelajaran berdasarkan: (1) Komunikatif; (2) Visual; (3) Layout interaktif; (4) Audio; dan (5) Keterbacaan konten. Dari hasil uji coba kelompok besar, skor yang didapat sebesar $92,71 \%$. Hal ini menunjukkan bahwa media pembelajaran telah memenuhi kriteria valid dalam aspek komunikasi visual. Namun skor yang masih belum sempurna. Hal ini menandakan masih ada sedikit kekurangan pada media pembelajaran. Oleh karena itu perlunya dilakukan perbaikan terhadap media pembelajaran khususnya pada aspek komunikasi visual, sehingga dapat menutupi kekurangan tersebut. Perbaikan yang dilakukan senada dengan teori yang dikatakan oleh Wahono (2007) bahwa sebuah media pembelajaran harus memiliki memiliki tampilan yang sederhana dan memikat, kemudian media pembelajaran juga harus memiliki keterbacaan yang jelas agar pengguna bisa menerima informasi dengan mudah. Untuk rincian persentase setiap aspek dapat dilihat pada Tabel 5.

Tabel 5. Hasil uji coba kelompok besar

\begin{tabular}{lcccc}
\hline \multicolumn{1}{c}{ Aspek } & NTse & $\sum$ Tsh & V (\%) & Kriteria \\
\hline Rekayasa Perangkat Lunak & 1329 & 1440 & 91,67 & Sangat Valid \\
Komunikasi Visual & 445 & 480 & 93,00 & Sangat Valid \\
\hline
\end{tabular}

Dari beberapa rangkaian validasi dan uji coba yang sudah dilakukan merujuk pada kriteria penilaian menurut Akbar (2013), maka secara keseluruhan media pembelajaran dapat dinyatakan sangat valid dan sangat layak digunakan sebagai suplemen penunjang siswa dalam belajar dimana saja dan kapan saja.

\section{Kesimpulan}

Media berupa web application yang telah dirancang sesuai dengan kebutuhan dan dengan mengintegrasikan gamifikasi, sehingga menjadi media pembelajaran pendukung pada mata pelajaran Pemrograman Dasar kelas X RPL di SMK Negeri 4 Malang. Media ini dikembangkan dengan menggunakan model penelitian dan pengembangan ADDIE. Media memuat 3 kompetensi, sehingga media dapat digunakan sebagai media pendukung mata pelajaran Pemrograman Dasar. Media pembelajaran ini telah valid dan layak digunakan berdasarkan penilaian dari validator dan subjek coba dengan persentase hasil akhir 91,93\%. Detail penilaian dari validator dan subjek coba sebagai berikut: (a) Hasil validasi pada validator media diperoleh persentase sebesar 94,17\% dengan kategori sangat valid; (b) Hasil validasi pada validator 


\section{TEKNO Jurnal Teknologi Elektro dan Kejuruan}

http://journal2.um.ac.id/index.php/tekno | ISSN 1693-8739 / 2686-4657

materi diperoleh persentase sebesar 95,24\% dengan kategori sangat valid; (c) Hasil uji coba pada subjek coba, diperoleh persentase sebesar $87,63 \%$ dengan kategori sangat layak pada uji coba kelompok kecil dan diperoleh persentase sebesar 91,93\% dengan kategori sangat layak pada uji coba kelompok besar.

\section{Daftar Rujukan}

Aini, Q., Rahardja, U., Moeins, A., dan Apriani, D. M. 2018. Penerapan Gamifikasi pada Sistem Informasi Penilaian Ujian Mahasiswa untuk Meningkatkan Kinerja Dosen. Jurnal Informatika Upgris, 4, 1, 46-55.

Akbar, S. dan Sriwijaya, H. 2010. Pengembangan Kurikulum dan Pembelajaran IImu Pengetahuan Sosial (IPS). Yogyakarta: Cipta Media.

Farida, Khoirunnisa, Y., dan Putra, R. W. Y. 2018. Pengembangan Bahan Ajar Gamifikasi pada Materi Bangun Ruang Sisi Lengkung. Jurnal Penelitian dan Pembelajaran Matematika, 11, 2, 193-204.

Jusuf, H. 2016. Penggunaan Gamifikasi dalam Proses Pembelajaran. Jurnal TICOM, 5, 1, 1-6.

Maryanto, H., Suyanto, M., dan Fatta, H. A. 2017. Penerapan Gamification Cashflow sebagai Media Pembelajaran Pengelolaan Keuangan Pribadi pada Anak Usia Dasar (Studi Kasus: SDN Plumpung 1 Plaosan Magetan). Jurnal Telematika, 10, 2, 166-178.

Prambayun, A. dan Farozi, M. 2015. Pola Perancangan Gamifikasi untuk Membangun Engagement Siswa dalam Belajar. SEMNASTEKNOMEDIA ONLINE, 3, 1, 5.7-11.

Pratomo, A. 2018. Pengaruh Konsep Gamifikasi terhadap Tingkat Engagement (Studi Kasus Pelatihan Karyawan the Park Lane Jakarta). The Journal: Tourism and Hospitality Essentials Journal, 8, 2, 63-74.

Rumansyah, M. 2016. Perbedaan Pengaruh Pembelajaran dengan menggunakan Modul Interaktif dan Modul Konvensional terhadap Pemahaman Konsep IPA. Jurnal Pendidikan Matematika dan Sains, 4, 1, 54-62.

Suhendi dan Adriansyah, A. R. 2018. Prototype Gamifikasi Situs-Situs Wilayah Depok menggunakan Perangkat Mobile. Ikraith-Informatika, 2, 2, 76-81.

Trisiana, A. dan Wartoyo. 2016. Desain Pengembangan Model Pembelajaran Pendidikan Kewarganegaraan melalui Addie Model untuk Meningkatkan Karakter Mahasiswa di Universitas Slamet Riyadi Surakarta. PKn Progresif, 11, 1, 312-330.

Wahono, R. S. 2007. Panduan Pengembangan Multimedia Pembelajaran. Jakarta: Ditjen Manajemen Pendidikan Dasar dan Menegah, Depdiknas.

Yulia, D. dan Arifin, M. 2016. Pengaruh Penggunaan Media Film Animasi dalam Pembelajaran IPS Terpadu terhadap Hasil Belajar Siswa Kelas VIII di SMP Kartini 1 Batam Tahun Pelajaran 2013/2014. Historia, 10, 31-45. 